ISSN (e)-2347-176x ISSN (p) 2455-0450

crossref DOI: https://dx.doi.org/10.18535/jmscr/v7i6.112

\title{
Incidence of HER2 overexpression in oral squamous cell carcinoma- A prospective study in a tertiary care centre in eastern India
}

\author{
Authors \\ Sunil Agrawala ${ }^{1}$, Aalapti Singh ${ }^{2}$, Venkata Rao Epari ${ }^{3}$, Twinkle Rout ${ }^{4}$, \\ Debiprasad Mohanty ${ }^{5}$, Manoj Sahoo $^{6}$, Surendra Nath Swain ${ }^{7}$, Sourav Mishra ${ }^{8, *}$ \\ ${ }^{1}$ Associate Professor, Dept of Surgical Oncology, IMS \& SUM Hospital, Bhubaneswar \\ ${ }^{2} \mathrm{PhD}$ Scholar, Dept of Community Medicine, IMS \& SUM Hospital, Bhubaneswar \\ ${ }^{3}$ Professor, Department of Community Medicine, IMS and SUM Hospital, Bhubaneswar \\ ${ }^{4}$ Phd scholar, Dept of Biotechnology, Soa University \\ ${ }^{5}$ Phd Scholar, Dept of Surgical Oncology, IMS \& SUM Hospital, Bhubaneswar, \\ ${ }^{6}$ Professor, Dept of Gastroenterology, IMS \& SUM Hospital, Bhubaneswar \\ ${ }^{7}$ Dept of Medicine, IMS \& SUM Hospital, Bhubaneswar \\ ${ }^{8}$ Associate Professor, Dept of Medical Oncology, IMS \& SUM Hospital, Bhubaneswar, \\ *Corresponding Author \\ Dr Surendra Nath Swain
}

Associate Professor, Department of Medicine, IMS and SUM Hospital, Siksha O Anusandhan Deemed to be University

\section{Abstracts}

Aim: HER 2/Neu, a member of EGFR family, is over expressed in some tumour. There is a large variation in the percentage of overexpression of HER 2 /Neu in western vs India, where chewing tobacoo is a common practice. The purpose of this study was to determine the tissue expressing of HER 2/neu in patients with Head \& Neck oral Squamous Cell Carcinoma (HNSCC) and any co-relation with its epidemiological parameter.

Methods: IHC was used to access tissue expression of HER 2/neu in 74 patients with HNSCC during period of 2016 to 2018. All patients were of oral cancer. Both biopsy and resected specimen taken for study.

Results: Out of 74 patients 21 patients (28.4\%) showed strong HER 2/Neu positivity. Those participated in this study were 63(85\%) male \& $11(14.9 \%)$ were female.

Socioeconomic status -31 patients (41.9\%) never gone to school, 61 patients (82.4\%) uses tobacco .All the 74 patients (100\%) presented with ulcer inside mouth (oral cavity) lesion with $13(17.5 \%)$ patients having comorbidities.

Conclusion: In our cases HER 2/Neu overexpression seen in $28.4 \%$ of cases. This finding suggest that further sub-analysis with reference to HER 2 as a prognostic marker \& its therapeutic implication is further required. Keywords; HER 2/Neu, Head and neck cancer. 


\section{Introduction}

According to The International Agency for Research on Cancer (IARC), head and neck squamous cell carcinoma (HNSCC) is the most commonly found cancer in $\operatorname{India}^{(1)}$, primarily affecting the male population. Globally, it has the seventh highest incidence ${ }^{(2,3)}$, reaching almost $6,00,000$ new cases each year, accounting for more than $2,50,000$ deaths every year ${ }^{(1,4)}$.

In India, higher prevalence of oral cancer is because of common habits of chewing and smoking tobacco ${ }^{(5)}$. Additionally, gender, low education level, living in rural areas, dietary habits and compromised oro-dental hygiene also contribute to high oral cancer prevalence ${ }^{(6)}$.

It is known that the five-year survival rate of patients with HNSCC is around $40-60 \%{ }^{(7)}$. Tumor recurrence is also high, perhaps because of advanced stages (III and IV) at the time of diagnosis, in most cases. In $20-30 \%$ of patients, locoregional recurrence and distant metastatic disease has been commonly observed ${ }^{(8)}$.

HER2, a $185-\mathrm{kDa}$ tyrosine kinase receptor is a member of the human epidermal growth factor receptor family. Given the frequent recycling of HER2 receptor heterodimers over the cell surface and their ability to reduce the rate ofligand dissociation,it is the most preferred dimerization partner amongst the protein family ${ }^{(12-14)}$.

This case series is an attempt to examine whether there is an overexpression of HER2 in HNSCC patients and if it can further be targeted as a treatment option or a prognostic factor, as HER2 targeted therapy has proven beneficial for various other cancers, such as breast and gastro-intestinal cancers $^{(15)}$.

\section{Materials \& Methods}

In this study, 74 diagnosed cases of HNSCC registered at the Institute of Medical Sciences\& SUM HOSPITAL, affiliated to Siksha ' $O$ ' Anusandhan (deemed to be University) in
Bhubaneswar, Odisha, have been evaluated between 2016-17.

With the Immunohistochemistry (IHC) Method, sections with $4 \mu$ thick formalin fixed paraffin embedded (FFPE) blocks of HNSCC tumor specimen from each patient were mounted on positively charged microscope slides. Dewaxing of the microscopic slides was done in xylene, followed by dehydration of sectionsin ethanol and rinsing in distilled water. Using DAKO Target Retrieval solution (DAKO, Carpinteria, CA), antigen retrieval was done. Endogenous peroxidase was quenched by $3 \% \quad \mathrm{H}_{2} \mathrm{O}_{2}$. The peroxidase-labelled polymer conjugated to goat anti-mouse HER2 method was used to detect antigen-antibody reaction (DAKO Envision System; DAKO Corporation, Carpinteria, CA). Antibodies were made at room temperature for 1 hour on HER2 (ErbB 2 antibody ab2428, DAKO Corporation, Denmark) in 1:200 dilution. Sections were then visualized with 3,3-diaminobenzidine as a chromogen for 5 minutes and counterstaining was done using Harris's hematoxylin. The slides were then washed in tap water, dehydrated and mounted with glass coverslips. Sections of breast cancer tissue previously found positive for HER2/neu were used as Positive Controls. Duplicated sections of the same HNSCC samples in which the primary antibody had been excluded and replaced, were used as Negative Controls. The expression of EGFR and HER2 in HNSCC tumor specimens was determined.

Statistical analysis was performed using SPSS version 20.0v software (IBM Corp., Armonk, NY, USA). Descriptive data were expressed as percentages, frequency distributions, and chi-square test was used to compare categorical data. A pvalue of $<0.05$ was considered statistically significant.

\section{Results}

Of the 74 patients, $63(85.1 \%)$ were male and 11 $(14.9 \%)$ were female. In the oral cavity, buccal 
mucosa was the most common site of cancer observed in 25 cases $(33.8 \%$ ), followed by cancer of tongue in 20 cases $(27 \%)$. Correlation of site of cancer and HER2/neu expression has not been found to be statistically significant $(\mathrm{p}=0.642)$. (Table 4)

The socio-economic profile (Table 1) of patients was observed as follows:

Table 1: HER2/neu expression correlation with gender and socio-economic status of patients

\begin{tabular}{|c|c|c|c|c|c|c|}
\hline \multirow{2}{*}{\multicolumn{3}{|c|}{ Factor }} & \multicolumn{2}{|c|}{ HER2 Expression } & \multirow{4}{*}{$\begin{array}{c}\begin{array}{c}\text { Chi Square } \\
\text { Value }\end{array} \\
0.405\end{array}$} & \multirow{4}{*}{$\begin{array}{c}\mathrm{p} \text {-value } \\
(\mathrm{p}<0.05 \text { significant }) \\
0.524\end{array}$} \\
\hline & & & Positive & Negative & & \\
\hline \multirow{2}{*}{ Gender } & \multirow{2}{*}{\multicolumn{2}{|c|}{$\begin{array}{c}\text { Male } \\
\text { Female }\end{array}$}} & 17 & 46 & & \\
\hline & & & 4 & 7 & & \\
\hline \multirow{11}{*}{$\begin{array}{l}\text { Socio- } \\
\text { Economic } \\
\text { Status }\end{array}$} & \multirow[t]{6}{*}{ Occupation } & Farmer & 3 & 9 & \multirow[t]{6}{*}{3.233} & \multirow[t]{6}{*}{0.664} \\
\hline & & Labourer & 7 & 18 & & \\
\hline & & Business & 2 & 4 & & \\
\hline & & Job & 6 & 19 & & \\
\hline & & Housewife & 3 & 2 & & \\
\hline & & Unemployed & 0 & 1 & & \\
\hline & \multirow[t]{5}{*}{ Education } & Uneducated & 8 & 23 & 3.469 & 0.483 \\
\hline & & Primary & 6 & 18 & & \\
\hline & & Upper Primary & 0 & 3 & & \\
\hline & & High School & 4 & 6 & & \\
\hline & & Secondary & 3 & 3 & & \\
\hline
\end{tabular}

31 out of 74 patients (41.9\%) were uneducated; 24 patients $(32.4 \%)$ were educated up to primary level; 3 patients $(4 \%)$ were educated up to upper primary level; 10 patients $(13.5 \%)$ were educated up to high school and 6 patients $(8.1 \%)$ were educated up to secondary level. Correlation of level of education and HER2/neu expression has not been found to be statistically significant $(\mathrm{p}=0.483)$. Majority of the patients were employed. 12 patients $(16.2 \%)$ were farmers, 25 patients (33.8\%) were labourers, 25 patients $(33.8 \%)$ were in a job, 6 patients $(8.1 \%)$ were in business and 5 patients $(6.8 \%)$ were housewives. Only one patient (1.3\%) was unemployed. Correlation of occupation of patients and HER2/neu expression has not been found to be statistically significant $(\mathrm{p}=0.664)$.

Table 2: HER2/neu expression correlation with co-morbidities and tobacco usage history of patients

\begin{tabular}{|c|c|c|c|c|c|}
\hline \multicolumn{2}{|l|}{ Factor } & \multicolumn{2}{|c|}{ HER 2 Expression } & \multirow[t]{2}{*}{ Chi Square Value } & \multirow{2}{*}{$\begin{array}{c}\mathrm{p}-\text { Value } \\
(\mathrm{p}<0.05 \text { significant })\end{array}$} \\
\hline & & Positive & Negative & & \\
\hline \multirow{2}{*}{ Co- Morbidity } & Yes & 3 & 10 & \multirow[t]{2}{*}{0.218} & \multirow[t]{2}{*}{0.614} \\
\hline & No & 18 & 43 & & \\
\hline \multirow{2}{*}{$\begin{array}{l}\text { Tobacco } \\
\text { Consumption History }\end{array}$} & Yes & 19 & 42 & \multirow[t]{2}{*}{1.310} & \multirow[t]{2}{*}{0.252} \\
\hline & No & 2 & 11 & & \\
\hline \multirow{4}{*}{$\begin{array}{l}\text { Typesof } \\
\text { Consumed }\end{array}$} & Smoking & 2 & 4 & \multirow[t]{4}{*}{2.398} & \multirow[t]{4}{*}{0.494} \\
\hline & Smokeless & 15 & 31 & & \\
\hline & Both & 4 & 14 & & \\
\hline & None & 0 & 4 & & \\
\hline
\end{tabular}

Out of all 74 patients, 13 patients $(17.5 \%)$ presented with co-morbidities such as diabetes and hypertension. Correlation of presence of comorbidities and HER2/neu expression has not been found to be statistically significant $(\mathrm{p}=0.614)$. (Table 2)

61 patients $(82.4 \%)$ consumed tobacco. Of them, 6 patients $(8.1 \%)$ smoked tobacco, 46 patients $(62.2 \%)$ chewed tobacco and 18 patients $(24.3 \%)$, both smoked as well as chewed tobacco.No statistical significance has been found for HER2/neu expression with tobacco consumption history $(p=0.252)$ and the types of tobacco consumed $(\mathrm{p}=0.494)$. (Table 2$)$ 
Overexpression of HER2/neu was detected in tumor specimens of only 21 patients $(28.4 \%)$ out of all 74 patients.(Table 3) Absence of expression of HER2/neu was seen in maximum number of patients $(71.6 \%)$ who presented with oral cancer at different sites (Table 4). No statistical significance has been found for HER2/neu expression and sites of oral cancer $(\mathrm{p}=0.642)$.

Table 3: HER2/neu expression in 74 patients of the study

\begin{tabular}{|l|c|c|c|}
\hline \multirow{2}{*}{} & \multicolumn{2}{|c|}{ HER 2 Expression } & \multirow{2}{*}{ Total } \\
\cline { 2 - 3 } & Positive & Negative & \\
\hline Numberof Patients (\%) & $21(28.4 \%)$ & $53(71.6 \%)$ & $74(100 \%)$ \\
\hline
\end{tabular}

Table 4: HER2/neu expression correlation with clinical diagnosis, cancer subgroup of patients

\begin{tabular}{|c|c|c|c|c|c|}
\hline \multirow{2}{*}{\multicolumn{2}{|c|}{ Factor }} & \multicolumn{2}{|c|}{ HER 2 Expression } & \multirow{2}{*}{$\begin{array}{l}\text { Chi Square } \\
\text { Value }\end{array}$} & \multirow{2}{*}{$\begin{array}{c}P \text { V Value } \\
(p<0.05 \text { significant })\end{array}$} \\
\hline & & Positive & Negative & & \\
\hline \multirow{17}{*}{ Diagnosis } & Ca Buccal Mucosa & 0 & 3 & \multirow[t]{17}{*}{26.651} & \multirow[t]{17}{*}{0.642} \\
\hline & Ca Rt Buccal Mucosa & 1 & 4 & & \\
\hline & CA Lt Buccal Mucosa & 3 & 14 & & \\
\hline & Ca Labiogingival Sulcus & 0 & 3 & & \\
\hline & Ca Rt Lower GB sulcus & 1 & 1 & & \\
\hline & Ca Upper GB Sulcus & 1 & 0 & & \\
\hline & Ca Left GB Sulcus & 2 & 4 & & \\
\hline & Ca Rt Lower Gingivum & 0 & 2 & & \\
\hline & Ca Lt Lower Gingivum & 1 & 2 & & \\
\hline & Ca Tongue & 8 & 12 & & \\
\hline & Ca Lower Lip & 1 & 1 & & \\
\hline & Ca Upper Lip & 0 & 1 & & \\
\hline & Ca Lt RMT & 0 & 3 & & \\
\hline & Ca Rt RMT & 1 & 1 & & \\
\hline & Ca Rt Lower Alveolus & 1 & 1 & & \\
\hline & Ca Cheek & 0 & 1 & & \\
\hline & Ca Head Palate & 1 & 0 & & \\
\hline Sub Group & Oral Cavity & 21 & 53 & 1.852 & 0.396 \\
\hline
\end{tabular}

\section{Discussion}

Biomarker testing, especially HER2 overexpression estimation must be done for all patients who are newly diagnosed with any cancer. Its purpose is to inspect if the HER2 gene on the seventeenth chromosome is overexpressed, as it is known to affect long-term outcome measures in patients, such as survival and recurrence. Since, in case of breast and gastro-intestinal cancers, HER2 targeted therapy has proven to be effective, we have examined if the same holds true for HNSCC and if HER2 overexpression can be used as targeted therapy $^{(15)}$.

In our study setting, buccal mucosa was the most common site of cancer in the oral cavity, observed in 25 cases $(33.8 \%)$, followed by cancer of tongue in 20 cases $(27 \%)$. This result is synchronous with the results reported by Manjari et al, with a slightly varying percentage from $38-50 \%^{(16)}$. However, buccal mucosa has been reported as the most common site for oral cavity cancer due to regular chewing of tobacco ${ }^{(17)}$.

There was no significant correlation between HER2/neu expression with gender, socio-economic status, tobacco consumption history, types of tobacco consumed and clinical diagnosis.

The American Society of Clinical Oncology (ASCO) has suggested two methods of determining HER2 expression- through Immunohistochemistry (IHC) and Fluorescent in situ hybridization (FISH) (18). There are established protocols designed for determining HER2 expression for gastric cancer, but no such protocols have yet been designed for HNSCC $^{(19)}$. Pathologists use IHC/FISH scoring 
techniques for HNSCC, which are also used for breast cancer. HER2 overexpression ranges from 0 $47 \%$ in $\mathrm{HNSCC}^{(20-22)}$.

Wilkman et al. reported that HER2/neu due to its over expression considered as a potential biomarker which distinguishes between the non-cancer from the cancer tissues,it also indicates the continuous change in its expression ${ }^{(23)}$. However; in our study, expression of HER2 among HNSCC was only $28.6 \%$. Conway et al. reported higher incidence of HNSCC in males than in females, attributable to behavioral and lifestyle pattern ${ }^{(24)}$. Though, a similar pattern is observed in this study. Since this study was hospital-based and not a community survey, it cannot be concluded that incidence of HNSCC is found to be higher in males.

\section{Conclusion}

On the basis of the data from this study, it can be concluded that HER2/neu is significantly expressed in the oral cancer sub-group of head and neck squamous cell carcinoma. However, overexpression of HER2/neu does not corroborate with gender, socio-economic status (education, occupation), comorbidities, tobacco consumption history, types of tobacco consumed and clinical diagnosis. Therefore, further research is needed to examine whether HER2/neu can act as a prognostic factor for HNSCC and if it can be targeted for treatment options.

\section{References}

1. Bray F, Ferlay J, Soerjomataram I, Siegel RL, Torre LA, Jemal A. Global cancer statistics 2018: GLOBOCAN estimates of incidence and mortality worldwide for 36 cancers in 185 countries. CA Cancer J Clin [Internet]. 2018 Nov 1 [cited 2019 Feb 13];68(6):394-424. Available from: http://doi.wiley.com/10.3322/caac. 21492

2. Pollock NI, Grandis JR. HER2 as a therapeutic target in head and neck squamous cell carcinoma [Internet]. Vol. 21, Clinical Cancer Research. 2015 [cited 2019 Feb 11]. p. 526-33. Available from: https://www.ncbi.nlm.nih.gov/pmc/articles/P MC4315724/pdf/nihms-644451.pdf

3. Union for International Cancer Control. LOCALLY ADVANCED SQUAMOUS CARCINOMA OF THE HEAD AND NECK [Internet]. 2014 Review of Cancer Medicines on the WHO List of Essential Medicines. 2014 [cited 2019 Feb 13]. Available from: https://www.who.int/selection_medicines/co mmittees/expert/20/applications/HeadNeck. pdf

4. Sharma M, Madan M, Manjari M, Bhasin TS, Jain S, Garg S. Prevalence of Head and Neck Squamous Cell Carcinoma ( HNSCC ) in our population: The clinic-pathological and morphological description of 198 cases . Patients and Methods: Int J Adv Res [Internet]. 2015 [cited 2019 Feb 11];3(1):827-33. Available from: http://www.journalijar.com

5. Yeole BB, Ramanakumar A V, Sankaranarayanan R. Survival from oral cancer in Mumbai (Bombay), India. Cancer Causes Control [Internet]. 2003 Dec [cited 2019 Feb 14];14(10):945-52. Available from:

http://www.ncbi.nlm.nih.gov/pubmed/14750 533

6. Güneri P, Çankaya H, Yavuzer A, Güneri EA, Erişen L, Özkul D, et al. Primary oral cancer in a Turkish population sample: Association with sociodemographic features, smoking, alcohol, diet and dentition. Oral Oncol [Internet]. 2005 Nov 1 [cited 2019 Feb 14];41(10):1005-12. Available from: https://www.sciencedirect.com/science/articl e/abs/pii/S1368837505001594?via\%3Dihub 7. de Lyra RR, de Macedo-Soares TDL va. A. 
Strategic alliance governance forms. Corp Ownersh Control [Internet]. 2011 Jan 1 [cited 2019 Feb 11];8(4 D):334-44. Available from: http://doi.wiley.com/10.3322/caac.21166

8. Vermorken JB, Specenier P. Optimal treatment for recurrent/metastatic head and neck cancer. In: Annals of Oncology [Internet]. 2010 [cited 2019 Feb 7]. p. vii252-vii261. Available from: http://www.ncbi.nlm.nih.gov/pubmed/20943 624

9. Coussens L, Yang-Feng TL, Liao YC, Chen E, Gray A, McGrath J, et al. Tyrosine kinase receptor with extensive homology to EGF receptor shares chromosomal location with neu oncogene. Science (80- ) [Internet]. 1985 Dec 6 [cited 2019 Feb 12];230(4730):1132-9. Available from: http://www.ncbi.nlm.nih.gov/pubmed/29999 74

10. Anderson NG, Ahmad T. ErbB receptor tyrosine kinase inhibitors as therapeutic agents. Front Biosci [Internet]. 2002 Sep 1 [cited 2019 Feb 7];7:d1926-40. Available from:

http://www.ncbi.nlm.nih.gov/pubmed/12161 338

11. Yarden Y, Sliwkowski MX. Untangling the ErbB signalling network [Internet]. Vol. 2, Nature Reviews Molecular Cell Biology. 2001 [cited 2019 Feb 7]. p. 127-37. Available from: http://www.nature.com/articles/35052073

12. Lenferink AEGG, Pinkas-Kramarski R, Van De Poll MLMM, Van Vugt MJHH, Klapper LN, Tzahar E, et al. Differential endocytic routing of homo- and hetero-dimeric ErbB tyrosine kinases confers signaling superiority to receptor heterodimers. EMBO J [Internet]. 1998 Jun 15 [cited 2019 Feb 11];17(12):3385-97. Available from: http://emboj.embopress.org/content/embojnl /17/12/3385.full.pdf

13. Lenferink AEG, Busse D, Flanagan WM, Yakes FM, Arteaga CL. ErbB2/neu kinase modulates cellular p27Kip1and cyclin D1 through multiple signaling pathways. Cancer Res [Internet]. 2001 Sep 1 [cited 2019 Feb 11];61(17):6583-91. Available from: http://www.ncbi.nlm.nih.gov/pubmed/11522 658

14. Tzahar E, Waterman H, Chen X, Levkowitz G, Karunagaran D, Lavi S, et al. A hierarchical network of interreceptor interactions determines signal transduction by Neu differentiation factor/neuregulin and epidermal growth factor. Mol Cell Biol [Internet]. 1996 Oct [cited 2019 Feb 11];16(10):5276-87. Available from: http://www.ncbi.nlm.nih.gov/pubmed/88164 40

15. Kibirova A, Hall SJ, Salken MA. HER2Positive Breast Cancer: Current Management | MDedge Hematology and Oncology [Internet]. Hospital Physician Hematology-Oncology Board Review Manual; 2018 [cited 2019 Feb 14]. p. 34-48. Available from: https://www.mdedge.com/hematologyoncology/article/165824/breast-cancer/her2positive-breast-cancer-current-management

16. Manjari M, Popli R, Paul S, Gupta VP, Kaholon SK. Prevalence of oral cavity, pharynx, larynx and nasal cavity malignancies in Amritsar, Punjab. Indian $\mathbf{J}$ Otolaryngol Head Neck Surg [Internet]. 1996 [cited 2019 Feb 14];48(3):191-5. Available from: https://link.springer.com/article/10.1007/BF 03048602

17. Ravi M, Mamata S, Kishore GR, Manish S, Anil K K, Mehrotra R, et al. Trends of prevalence and pathological spectrum of 
head and neck cancers in North India. Indian J Cancer [Internet]. 2005 [cited 2019 Feb 14];42(2):89-93. Available from: http://www.indianjcancer.com

18. Wolff AC, Hammond MEH, Hicks DG, Dowsett M, McShane LM, Allison KH, et al. Recommendations for human epidermal growth factor receptor 2 testing in breast cancer: American society of clinical oncology/college of American pathologists clinical practice guideline update. Arch Pathol Lab Med [Internet]. 2014 Feb [cited 2019 Feb 11];138(2):241-56. Available from:

http://www.archivesofpathology.org/doi/abs/ 10.5858/arpa.2013-0953-SA

19. Rüschoff J, Hanna W, Bilous M, Hofmann M, Osamura RY, Penault-Llorca F, et al. HER2 testing in gastric cancer: A practical approach [Internet]. Vol. 25, Modern Pathology. 2012 [cited 2019 Feb 11]. p. 637-50. Available from: http://www.nature.com/articles/modpathol20 11198

20. Cavalot A, Martone T, Roggero N, Brondino G, Pagano M, Cortesina G. Prognostic impact of HER-2/neu expression on squamous head and neck carcinomas. Head Neck [Internet]. 2007 Jul [cited 2019 Feb 11];29(7):655-64. Available from: http://www.ncbi.nlm.nih.gov/pubmed/17315 173

21. Sardari Y, Pardis S, Tadbir AA, Ashraf MJ, Fattahi MJ, Ebrahimi H, et al. HER2/neu Expression in Head and Neck Squamous Cell Carcinoma Patients is not Significantly Elevated. Asian Pacific J Cancer Prev [Internet]. 2012 [cited 2019 Feb 11];13(6):2891-6. Available from: http://www.ncbi.nlm.nih.gov/pubmed/22938 479
22. Angiero F, Sordo R Del, Dessy E, Rossi E, Berenzi A, Stefani M, et al. Comparative analysis of c-erbB-2 (HER-2/neu) in squamous cell carcinoma of the tongue: Does over-expression exist? And what is its correlation with traditional diagnostic parameters? J Oral Pathol Med [Internet]. 2008 Mar 29 [cited 2019 Feb 11];37(3):14550. Available from: http://doi.wiley.com/10.1111/j.16000714.2007.00603.x

23. Wilkman TSE, Hietanen JHP, Malmström MJ, Konttinen YT. Immunohistochemical analysis of the oncoprotein c-erbB-2 expression in oral benign and malignant lesions. Int $\mathbf{J}$ Oral Maxillofac Surg [Internet]. 1998 Jun [cited 2019 Feb 14];27(3):209-12. Available from: http://www.ncbi.nlm.nih.gov/pubmed/96620 15

24. Conway DI, Petticrew M, Marlborough H, Berthiller J, Hashibe M, Macpherson LMD. Socioeconomic inequalities and oral cancer risk: A systematic review and meta-analysis of case-control studies. Int $\mathbf{J}$ Cancer [Internet]. 2008 Jun 15 [cited 2019 Feb 11];122(12):2811-9. Available from: http://doi.wiley.com/10.1002/ijc.23430. 